

THE ART OF

CLASSIC

PLANNING

BUILDING BEAUTIFUL

AND ENDURING COMMUNITIES 



\section{THE ART OF}

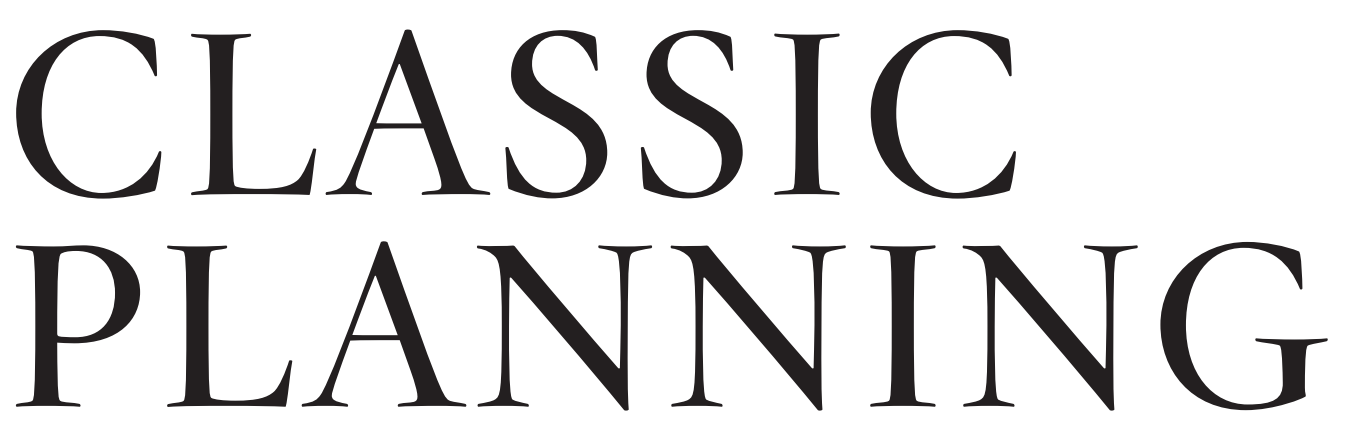

BUILDING BEAUTIFUL

AND ENDURING COMMUNITIES

\section{NIR HAIM BURAS}


Copyright () 2019 by the President and Fellows of Harvard College All rights reserved

Printed in the United States of America

\section{First printing}

Design and typesetting by 2K/DENMARK A/S

Library of Congress Cataloging-in-Publication Data

Names: Buras, Nir Haim, 1952- author.

Title: The art of classic planning : building beautiful and enduring communities / Nir H. Buras.

Description: Cambridge, Massachusetts: The Belknap Press of Harvard

University Press, 2019. | Includes bibliographical references and index.

Identifiers: LCCN 2019008309 | ISBN 9780674919242 (alk. paper)

Subjects: LCSH: City planning. | Civic improvement. | Architecture, Modern-2Oth century.

Classification: LCC NA9031 .B875 2019| DDC 724/.6-dc23

LC record available at https://lccn.loc.gov/2019008309

The Richard H. Driehaus Foundation.
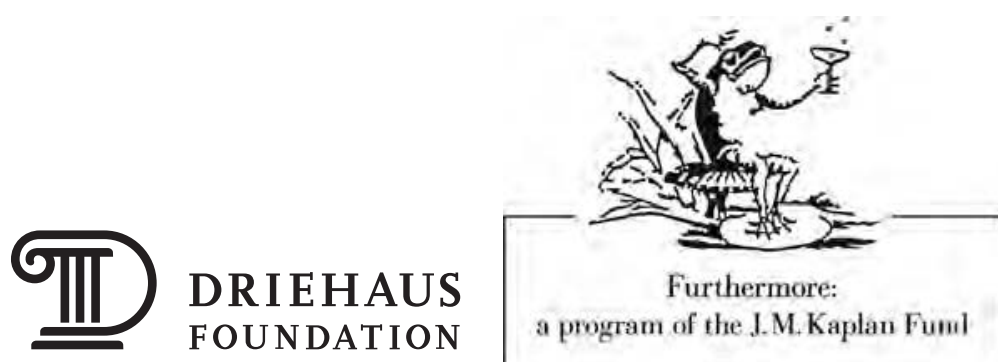
This book is dedicated to my mother, Netty, a devoted daughter, wife, mother, microbiologist, immunologist, and virologist, from whom I learned about life, and who declared on her deathbed, "Everything is good"; and to my father, Nathan, a surveyor, cartographer, water resources engineer, and operations research mathematician, who taught me geometry on the living room floor when I was seven, took me around the world when I was ten, paved a life path with milestones that I have tried to follow, and declared on his deathbed, "It is time for a new beginning." To Morgan and Noa, my guiding lights; to Luanne, who made it all possible; to my classical mentor Seth Weine; to Léon Krier for his inspiration; to Prince Charles, for heroically insisting on beauty in a world increasingly denying it; and to the reader, who may actually need this book. 
